\title{
PENGEMBANGAN PARIWISATA DI RUPAT UTARA DALAM PERSPEKTIF SUSTAINABLE TOURISM
}

\author{
Jesika Puteri $^{1}$, Syafri Harto ${ }^{2}$, Adianto ${ }^{3}$ \\ ${ }^{123}$ Universitas Riau \\ Riau, Indonesia \\ Jesika.puteri7022@grad.unri.ac.id ${ }^{1}, \underline{\text { Syafriharto@lecturer.unri.ac.id }}{ }^{2}$, \\ Adianto@lecturer.unri.ac.id
}

\begin{abstract}
The tourism sector plays an important role in supporting the economy, this makes tourist receiving countries competing to develop the tourism industry. Various efforts have been made to make tourist destinations attractive and able to generate as many tourist visits as possible. Researchers want to see the extent of tourism development in North Rupat based on available data in the relevant Office, as well as the extent of realization in the development of North Rupat Island as stated in the 2016-2021 National Tourism Strategic Area Plan, which is targeted this year and whether tourism development has been realized. sustainably. Researchers also want to see and find out what are the inhibiting factors in tourism development in Bengkalis Regency. This research method is qualitative which results in the finding that tourism development in the perspective of Sustainable Tourism in North Rupat, Bengkalis Regency through the application of the nine principles of sustainable tourism in the North Rupat tourism area has not run as a whole.
\end{abstract}

Keywords: Development, Tourism, Sustainable Tourism.

\section{PENDAHULUAN}

Undang-Undang Nomor 50 Tahun 2011 tentang Kepariwisataan menjelaskan bahwa pariwisata adalah berbagai macam kegiatan wisata dan didukung berbagai fasilitas serta layanan yang disediakan oleh masyarakat, pengusaha, pemerintah dan pemerintah daerah.Kepariwisataan adalah keseluruhan kegiatan yang terkait dengan pariwisata dan bersifat multidimensi serta multidisiplin yang muncul sebagai wujud kebutuhan setiap orang dan Negara. Pengelolaan sangat penting dilakukan pada suatu objek wisata karena merupakan suatu perubahan keadaan kondisi yang diterapkan. Tanpa dilakukan pengelolaan pada suatu objek wisata maka tidak ada perkembangan dan perubahan yang terjadi terhadap objek tersebut. Dengan pengelolaan sektor kepariwisataan yang baik, sektor pariwisata mampu menciptakan lapangan kerja, lapangan usaha bagi masyarakat serta dapat menggerakkan perekonomian bagi Negara maupun daerah.Pengembangan pariwisata merupakan salah satu bentuk pembangunan sektor pariwisata yang sangat diperlukan dalam rangka meningkatkan daya tarik wisatawan untuk berkunjung. Pariwisata yang dikelola dengan baik juga akan menambahkan salah satu pemasukan Pendapatan Asli Daerah (PAD). 
Pengelolaan dan pengembangan pariwisata diperlukannya sebuah strategi yang akan dilakukan serta kerjasama antara Pemerintah, Pemerintah Daerah, Swasta, dan Masyarakat seperti yang dijelaskan dalam pasal 11 Undang-Undang Nomor 10 Tahun 2009 tentang "Kepariwisataan."

Sektor pariwisata saat ini menjadi sebagai bagian pokok dari kebutuhan atau gaya hidup manusia, dan menggerakkan jutaan manusia untuk mengenal alam dan budaya kebelahan atau kawasan-kawasan dunia lainnya. Bagi pemerintah daerah dalam rangka pelaksanaan pembangunanpembangunan didaerah agar tercapai dan berkesinambungan, sumber-sumber pembiayaan merupakan salah satu faktor penentu dalam pencapaian tujuan yang diinginkan. Dengan kewenangan yang ada, Pemerintah Daerah harus jeli dalam menggali potensi-potensi kekayaan daerah yang dimilikinya guna meningkatkan Pendapatan Asli Daerah sehingga dapat membiayai pembangunan di daerah tersebut. Pengalaman selama ini menunjukkan bahwa hampir semua daerah persentase PAD relatif kecil.

Pulau RupatUtara merupakan salah satu anugerah alam terindah yang berada di Kabupaten Bengkalis yang juga memiliki potensi wisata yang bernilai tinggi. Pulau ini memiliki luas wilayah $1.524 \mathrm{~km}$ yang berbatasan langsung dengan Selat Malaka. Rupat Utara merupakan Pulau terluar Indonesia yang berbatasan langsung dengan Malaysia. Selain itu, pulau ini juga berbentuk gunung kecil di tengah laut luas yang juga memiliki posisi yang sangat strategis, karena langsung berhadapan dengan perairan internasional yang sangat ramai, yaitu selat Malaka. Pulau Rupat memiliki nilai yang sangat eksotis, karena kapal-kapal asing yang melintas di selat Malaka bisa langsung merapat ke Pulau ini. Pulau Rupat Utara juga memiliki pasir putih terpanjang di Indonesia, yang mana terdapat pantai dengan pasir putihnya membentang sepanjang $\pm 17 \mathrm{~km}$ mulai dari desa Teluk Rhu, Tanjung Samak ( Rupat Utara) sampai dengan Sungai Cingam (Rupat). Pantai yang lebarnya \pm 30 Meter jika air surut atau sekitar \pm 7 Meter saat air pasang. Karena memiliki pariwisata yang sangat berpotensi, maka perlu dilakukan pengembangan lebih lanjut.

Pulau Rupat memiliki banyak sekali potensi wisata yang menarik. Diantara beberapa Potensi tersebut dapat dibagi kedalam 3 jenis yaitu wisata wisata alam, wisata budaya, dan wisata buatan. Yang pertama potensi wisata alam yaitu sebagaimana Pulau Rupat memiliki atraksi wisata alam yang bersumber dari objek wisata pantai yang sangat terbuka lebar dan menyuguhkan pemandangan alam pantai 
yang sangat mempesona dan unik yaitu hamparan pasir putih yang panjang dan bersih, ombak yang besar memungkinkan unntuk berselancar dan menyelam. Lalu ada pula wisata alam mangrove yang sangat luas dan ada beragam habitat ekosistem yang ada didalamnya baik itu flora maupun fauna.Potensi wisata yang kedua yaitu wisata Budaya berupa kearifan lokal yang mempunyai nilai sangat tinggi. Wisata budaya ini berupa Makam Puteri Sembilan yang mempunyai legenda dalam Melayu, Kelenteng yang dibangun oleh Masyarakat Budha dengan design yang sangat unih dan juga megah. Ada pula keunikan dari masyarakat Komunitas Adat Terpencil (KAT) Suku Akit yang masih kental dengan budayanya, yaitu dengan menampilkan tarian budaya sukunya seperti tarian zapin api yang biasanya dilakukan setahun sekali dan pada kegiatan besar baik diadakan oleh masyarakat setempat ataupun dari Pemerintah Kabupaten Bengkalis. Potensi yang ketiga yaitu wisata buatan, yang dibuat untuk mendukung wisata yang sudah ada agar lebih menarik lagi. Wisata buatan ini diantaranya Mandi Safar di Desa Tanjung Punak Kecamatan Rupat Utara, yang mana mandi safar ini dilakukan pada tahun hijriyah dan dimeriahkan dengan atraksi zapin api, festival sumpit, dan perayaan peringatan kelenteng di Tanjung
Medang, serta ada pula festival Pantai Rupat yang dilakukan setahun sekali.

Oleh karena itu, untuk Menunjang pengembangan kawasan Rupat Utara sebagai kawasan strategis pariwisata nasional, maka dinilai kawasan di sekitarnya perlu dikembangkan. Untuk mendukung pengembangan maka dibuatlah Rencana Kawasan Stategis Pariwisata Nasional (RKSPN) Rupat Utara 2016-2021 yaitu targetnya pada tahun ini.

Dalam rangka Menunjang kawasan Rupat Utara sebagai kawasan strategis pariwisata nasional, maka kawasan di sekitarnya perlu dikembangkan untuk mendukung pengembangan Kawasan Stategis Pariwisata Nasional (KSPN) Rupat Utara.

Rencana Penunjang Kawasan Srategis Pariwisata Nasional (KSPN) Rupat Utara Tahun 2016-2021 diatas, dapat dilihat bahwa terdapat beberapa pengembangan pada kawasan wisata Rupat Utara yaitu diantaranya pengembangan destinasi wisata yang yang dapat dilihat dengan adanya pembangunan fasilitas yang berupa hotel berbintang, wahana permainan air, restoran dan café yang, meeting room, pelantar wisata perahu dan jetty, perbaikan sarana prasarana, dan jalan akses menuju objek wisata. Lalu pengembangan pada event pendukung pariwisata yang dapat dilihat dengan adanya pembangunan vihara 
terbesar di Asia, event tour de siak. Pengembangan aksebilitas dapat dilihat dari adanya pembangunan bandar udara di Rupat Utara, peningkatan pelabuhan, internasional Tanjung Medang-Malaysia. Pengembangan amenitas dapat dilihat dengan adanya pembangunan dan peningkatan jalan lingkar Rupat Utara, Rumah Sakit Umum Daerah, fasilitas perbankan, pembangunan turap pengaman pantai yang abrasi, peningkatan penyediaan layanan air bersih, pengembangan jaringan drainase terpadu, peningkatan pengelolaan sampah. Selain dari beberapa pengembangan yang terlaksana diatas, tidak sedikit pula yang belum terealisasikan diantaranya mulai dari Pengembangan destinasi wisata seperti pembangunan Pendopo, pembangunan WC/Ruang ganti, pembangunan fasilitas objek pariwisata seperti Pintu Gerbang, tempat duduk, toilet, kamar bilas. pembangunan museum Suku Akit Ratas, pengembangan rumah tradisional suku akit ratas. Sampai dengan pengembangan Amenitas seperti pembangunan dan peningkatan jalan lingkar Pulau Rupat (Desa Tanjung Kapal Desa Pangkalan Nyirih), pembangunan turap pengaman pantai yang abrasi (tempat tertentu saja), pembangunan pemecah ombak untuk mengurangi potensi abrasi (tempat tertentu saja), Peningkatan penyediaan layanan air bersih (tempat tertentu saja), Peningkatan kualitas jaringan listrik yang belum merata di kawasan Rupat Utara tersebut.

Pengembangan pariwisata di Rupat Utara secara berkelanjutan tentunya memiliki beberapa unsur pendukung yaitu diantaranya partisipasi masyarakat lokal untuk ikut serta dalam mengontrol pembangunan pariwisata, mengidentifikasi sumber daya yang akan dipelihara dan ditingkatkan serta mengembangkan tujuan dan strategi untuk pembangunan kawasan wisata yang dalam hal ini dapat melalui perwakilan POKDARWIS (Kelompok Sadar Wisata) yaang berada di Rupat Utara yang akan turut serta berpartisipasi dalam pengembangan kawasan wisata.

Fasilitas merupakan faktor pendukung yang sangat penting harus tersedia untuk menunjang pengembangan wilayah KSPN Rupat Utara. Fasilitas dalam hal ini merupakan bangunan fisik yang juga merupakan tolak ukur penentu berhasil tidaknya pengembangan suatu kawasan wisata. Dengan adanya kawasaan wisata, maka akan ada wisatawan yang akan berkunjung dan tentu saja membutuhkan fasilitas sebagai bentuk pelayanan untuk menarik perhatian wisatan dan mencipatakan kesan agar tertarik untuk kembali lagi. Misalnya saja fasilitas yang paling utama sekali jika ingin berkunjung adalah fasilitas transportasi, jika 
transportasi saja susah maka secara tidak langsung dapat mengurangi ketertarikan npengunjung untuk datang kembali. Fasilitas pendukung pariwisata merupaka bangunan fisik yang disedikan oleh pemerintah daerah ataupun swasta.

ketersediaan fasilitas belum memadai. Padahal, fasilitas merupakan faktor pendukung yang sangat penting dalam menunjang pegembangan kawasan wisata secara berkelanjutan. Beberapa lokasi kawasan wisata sudah memiliki penginapan namun jaraknya agak jauh dari lokasi wisata dan bahkan beberapa kawasan yang tidak menyediakan penginapan sama sekali. Padahal penginapan merupakan fasilitas teerpenting yang harus tersedia didekat lokasi wisata. Selain penginapan, warung makan juga sangat penting harus tersedia karena makanan merupakan kebutuhan pokok. Ada beberapa tempat yang menyediakan warung makan, tetapi hanya sedikit dan warung kecil yang menjual makanan tertentu saja. Sinyal hp jugua tak kalah pentingnya, tetapi jika wisatawan ingin berlibur menikmati alam dengan tanpa harus terganggu oleh kesibukan rutinitas mungkin kawasan wisata ini cukup menenangkan karena keindahan alamnya dan jauh dari kesibukan kota yang riuh. Pulau Beting Aceh merupakan primadona yang menyediakan pantai sangat indah dengan pasir putihnya, namun sayangnya pulau ini sangat minim bahkan tidak ada fasilitas yang tersedia yang hanya sekedar menyediakan fasilitas transportasi saja untuk menuju kawasan tersebut. Keberadaan fasilitas dan sarana yang sudah ada di kawasan wisata Rupat Utara ini harus didukung sektor lain agar wisatawan semakin betah. Biasanya, setiap orang yang datang butuh makan, minum dan membeli cenderamata. Untuk itu, Pemerintah Kabupaten Bengkalis mendorong warga setempat untuk menyediakan kuliner khas Melayu, khususnya Rupat Utara, seperti seafood. Pembuatan cenderamata dibutuhkan kreatifitas masyarakat setempat yang bisa membuat sesuatu berbentuk unik. Untuk pengembangan pariwisata di Pantai Rupat Utara maka perlu adanya peningkatan dan penyediaan fasilitasfasilitas atau sarana dan prasarana yang mendukung peningkatan potensi kepariwisataan seperti fasilitas akomodasi hotel yang memadai dan memiliki pelayanan yang bagus, kemudahan transportasi, infrastruktur, restoran dan fasilitas lainnya serta jasa-jasa pelayanan pariwisata yang baik. Fokus utama pengembangan adalah akomodasi yakni Hotel Resort yang tentunya akan menjadi wadah bagi wisatawan untuk menginap dan tinggal lebih lama di Pulau Rupat untuk menikmati keindahan pantai pasir putih di Rupat Utara tentunya menjadi hal yang 
menguntungkan jika wisatawan menginap dan memperpanjang length of stay dan pastinya akan membelanjakan uang yang lebih banyak pula.

Jika dilihat dari tahun ke tahun pembangunan dan pengembangan kawasan wisata Kecamatan Rupat Utara tidak mengalami perubahan yang singnifikan dan hanya dalam waktu tertentu saja. Adapaun masalah yang terlihat diantaranya yaitu akses menuju kawasan wisata Rupat Utara yang sangat jauh tidak didukung dengan Infrastruktur Jalan memadai menuju Kawasan wisata Rupat Utara seperti pembangunan jalan yang belum terselesaikan sama sekali, banyaknya kondisi jalan yang rusak menjadi penghambat pengembangan kawasan wisata yang berpengaruh dengan minimnya pengunjung yang datang ke kawasan wisata Rupat Utara, selain itu fasilitas pelayanan pendukung yang belum mencukupi di sekitar kawasan wisata Rupat Utara seperti Seperti Rumah Makan, Toko Cendramata, penginapan, dll. Padahal, jika diolah dengan baik kawasan wisata tersebut dapat menambah peluang kerja baru bagi masyarakat sekitar dengan membuka tempat penginapan, rumah makan, cendramata/ oleh-oleh yang merupakan hasil dari penduduk sekitar lalu dijual kepada wisatawan secara tidak langsung itu akan ikut mensejahterakan masyarakat sekitar. Namun ,harus turut adannya campur tangan pemerntah untuk dapat mensosialisasikan dan membimbing dalam proses tersebut. Sejauh ini pemerintah melalui dinas pariwisata yang paling berperan dalam mengembangkan kawasan wisata Rupat Utara, tetapi itu saja tidak cukup tanpa adanya dukungan dari masyarakat dan swasta tentunya yang menjadi salah satu faktor pengembangan kawasan wisata yang mana harus ada partisipasi. Oleh karena itu, peneliti ingin melihat sejauh mana pengembangan pariwisata di Rupat Utara berdasarkan data yang yang ada di Dinas terkait, serta sejauh mana realisasi dalam pengembangan Pulau Rupat Utara yang tertera dalam Rencana Kawasan Strategis Pariwisata Naisonal 2016-2021 yaitu ditargetkan pada tahun ini dan apakah sudah terealisasi pembangunan wisata secara berkelanjutana. Peneliti juga ingin melihat dan mengetahui apa saja yang menjadi faktor penghambat dalam pengembangan pariwisata di Kabupaten Bengkalis. Berangkat dari latar belakang diatas, peneliti tertarik untuk melakukan penelitian dengan judul Pengembangan Pariwisata Di Rupat Utara Dalam Perspektif Sustainable Tourism.

\section{METODE PENELITIAN}

Jenis penelitian yang ini menggunakan jenis penelitian kualitatif 
dengan pendekatan studi kasus. Creswell dalam Herdiansyah, (2010:76) menyatakan bahwa studi kasus adalah suatu model yang menekankan pada eksplorasi dari suatu system yang terbatas pada sutu kasus atau beberapa kasus yang secara menetil, diserai dengan penggalian data yang mendalam.

Proses penelitian ini kualitatif dengan melibatkan upaya-upaya penting dalam mengumpul data mengenai pengembangan kawasan wisata Rupat Utara dari beberapa informan yang telah peneliti tetapkan, seperti mengajukan pertanyaan-pertanyaan ataupun wawancara mendalam mengenai pengembangan kawasan wisata Kecamatan Rupat Utara Kabupaten Bengkalis, Sugiyono (2018) mengemukakan, dalam penelitian kualitatif, data diperoleh dari berbagai sumber dengan menggunakan teknik pengumpulan data yang bermacammacam (triangulasi) dan dilakukan secara terus menerus hingga datanya jenuh. Analisis data adalah upaya atau cara untuk mengolah data menjadi informasi sehingga karakteristik data tersebut bisa dipahami dan bermanfaat untuk solusi permasalahan terutama yang terkait dengan penelitian, yang terdiri dari pengumpulan data, reduksi data, penyajian data, dan penarikan kesimpulan.

SertaInforman merupakan orang yang benar- benar mengetahui permasalahan yang akan diteliti. Dalam penelitian ini, informan peneliti doambil dengan menggunakan metode purposive sampling.

\section{PEMBAHASAN}

Pengertian pengembangan menurut Damantik dan Weber (2006:11) merupakan segala sesuatu hal mengenai kegiatan dan usaha yang terkoordinasi untuk menarik wisatawan, menyediakan semua sarana dan prasarana, barang dan jasa serta semua fasilitas yang diperlukan guna melayani kebutuhan wisatawan. Segala kegiatan dan perkembangan pariwisata meliputi segi-segi yang amat luas dan menyangkut berbagai segi kehidupan dalam masyarakat, mulai dari kegiatan angkutan, akomodasi, atraksi wisata, makanan dan minuman, cinderamata, suasana kenyamanan serta pelayanan yang diberikan terhadap wisatawan itu sendiri.

Istilah pariwisata (tourism) baru mancul di masyarakat di masyarakatkirakira pada abad ke-18, khususnya sesudah Revolusi Industri di Inggris.Istilah pariwisata berasal dari dilaksanakannya kegiatan wisata (tour), yaitusuatu aktivitas perubahan tempat tinggal sementara dari seseorang, di luartempat tinggal sehari-hari dengan suatu alasan apa punselain melakukan kegiatan yang bisa 
menghasilkan upah atau gaji (Muljadi,2012).

Pariwisata yaitu kegiatan melakukan perjalanan dengan tujuan mendapatkan kenikmatan, mencari kepuasan, mengetahui sesuatu, memperbaiki kesehatan, menikmati olahraga atau istirahat, menunaikan tugas, dan lain-lain. Defenisi yang luas pariwisata adalah perjalanan dari suatu tempat ketempat lain, bersifat sementara,dilakukan perorangan maupun kelompok, sebagai usaha mencari keseimbangan atau keserasiandan kebahagiaan dengan lingkungan hidup dalam dimensi sosial, budaya,alam dan ilmu. Suatu perjalanan akan dianggap sebagai perjalanan wisata bila memenuhi tiga persyaratan yang diperlukan, yaitu bersifat sementara dan juga dapat bersifat sukarela (Voluntary) dalam arti tidak terjadi karena paksaan, dantidak bekerja yang sifatnya menghasilkan upah (Spillane dalam

\section{Siallagan,2011).}

Pariwisata adalah keseluruhan dari elemen-elemen terkait (wisatawan, daerah tujuan wisata, perjalanan, industri, dan lainlain) yang merupakan akibat dari perjalanan wisata ke daerah tujuan wisata, sepanjang perjalanan tersebut tidak permanen.

(Murphy dalam Sedarmayanti, 2014)

Yoeti dalam Risky (2016 : 24) menyatakan bahwa pariwisata adalah sesuatu usaha rangkaian yang dilakukan oleh pemerintah, swasta dan masyarakat untuk meningkatkan, memelihara ataupun membangun, baik secara kuantitatif maupun secara kualitatif terhadap ciptaan Tuhan, manusia, tata hidup. Seni budaya atau keadaan alam yang mempunyai daya tarik untuk dikunjung atau dinikmati oleh wisatawan.

Kawasan wisata Rupat Utara memiliki pantai yang sangat indah dan menjadi wisata unggulan yaitu pantai lapin dan pulau beting aceh, yang mana pantai lapin sendiri merupakan destinasi wisata utama yang menjadi ikon rupat utara dan sering dikunjungi karena keindahan pantainya dengan pasir putih yang membentang sepanjang $17 \mathrm{~km}$. Pulau Rupat dulunya merupakan suatu pulau yang cukup terisolir karena letaknya jauh dari kota sehingga perkembangan pembangunan sangat lambat. Semenjak adanya jalan tol Pekanbaru-Dumai, berdampak juga terhadap daya tarik wisata yang ada di Rupat Utara karena mempersingkat waktu tempuh wisatawan dari Pekanbaru untuk berkunjung menikmati keindahan alam Pulau Rupat yang kini namanya mulai terkenal dengan keindahannnya. Jika menggunakan motor untuk menuju Pulau Rupat juga sebenarnya bisa melalui akases pelabuhan selenseng dengan menggunakan kapal kayu kecil dan merapat di pelabuhan pergam yang mana dari pelabuhan ini ke 
rupat Utara dapat mempersingkat waku lebih cepat satu jam dibandingkan dari pelabuhan roro dumai, namun tidak bisa setiap saat karena jadwalnya menunggu air pasang sekitar pagi jam 10 dan jam 5 sore. Pelabuhan penyebrangan selenseng ini tentunya tidak resmi dan tidak punya standar keamanan yang memadai bagi penumpang hanya saja jaraknya lebih dekat sehingga pengendara motor biasanya banyak yang memilih akses penyebrangan ini.

Namun demikian, tetap saja akses jalan ketika sampai di pulau rupat masih buruk karena masih sebagian kecil yang merupakan jalan aspal dan selebihnya berupa jalan bebatuan / jalan pengerasan, dan jalan tanah. Jelas saja dengan kondisi jalan seperti itu cukup menghambat perjalanan menuju kawasan wisata di Rupat Utara yang letaknya agak jauh dari pelabuhan penyebrangan dan ketika hujan sedikit saja maka jalanan akan licin dan jalanan tanah yang tentu saja membuat kendaraan terpuruk sehingga menyebabkan atrtian kendaraan yang ingin melintas terhalang. Aliran listrik juga belum merata dirasakan oleh masyarakat, dan sering ada kendala listrik juga di kawasan rupat utara belum seperti kawasan lainnya yang berada di Kabupaten Bengkalis. Potensi yang ada juga belum dikelola dan dimanfaatkan secara maksimal. Hal ini terlihat dari penyediaan komponen wisata yang ada di Pulau Rupat masih kurang memadai untuk daerah tujuan wisata, sehingga dapat menyebabkan minat pengunjung atau wisatawan sangat rendah. Selain permasalahan kurang tersedianya komponen pariwisata, Pulau Rupat ini merupakan kawasan yang terisolir karena minimnya infrastrukur wilayah, keterbatasan prasana dan sarana yang memadai untuk kemudahaan pergerakan serta masalah pertanahan dan keamanan. Berangkat dari beberapa masalah diatas, jika ingin mengembangkan kawasan Rupat Utara menjadi kawasan wisata berkelanjutan maka perlu memperhatikan prinsip-prinsip dalam sustainable tourismyang akan dipaparkan pada penjelsan berikut.

\section{Partisipasi}

Berdasarkan analisis yang telah peneliti lakukan, maka dapat disimpulkan partisipasi dalam pengembangan pariwisata yang berbasis sutainable tourism di Kawasan wisata Rupat Utara Kabupaten Bengkalis sudah terpenuhi . Partisipasi dalam pengembangan pariwisata dalam perspetif Sistainable Tourism ini dapat dilihat dari peran masing-masing pelaku pengembangan seperti pemerintah selaku penyedia fasilitas umum dan dapat dinikmati secara gratis oleh pengunjung dilokasi wisata serta memberikan pelatihan 
sebagai kooordinator yang memberi instruksi kepada swasta dan masyarakat. Swasta selaku penyedia kebutuhan atau penyedia fasilitas pendukung yang dibutuhkan oleh wisatawan seperti penginapan dan spot wisata buatan. Masyarakat berpartisipasi dalam pengembangan pariwisata berkelanjutan ini yaitu melalui pokdarwis dengna berpartisipasi dalam Musrenbang yang dilakukan sekali setahun untuk menyampaikan aspirasi masyarakat, serta berperan serta juga dalam kegiatan yang diselenggarakan dalam rangka promosi wisata sebagai pengisi acara dan penyedia kuliner dan lain sebagainya berdasarkaan kebutuhan.

\section{Aspek Keikutsertaan Para} Pelaku/Stakeholders

Keikutsertaan para pelaku merupakan keterlibatan para pihak terkait yangdalam hal ini pada pariwisata berkelanjutan, sesuai dengan peran masing-masing pelaku. Keikutsertaan para pelaku atau unsur pengembangan pariwisata di Kawasan wisata Rupat Utara terdiri dari penyediaan fasilitas pendukung kegiatan wisatawan dan pengelolaan fasilitas wisatawan. Peran dari pemerintah daerah berupa penyediaan fasilitas berupa gazebo, pergola, pendopo, jogging track, mushola, toilet, dan lain sebagainya. Swasta sebagai pihak penyedia fasilitas penginapan dan tempat makan.
Masyarakat berperan sebagai pengelola dankaryawan dari penginapan yang disediakan oleh swasta serta penyedia fasilitas pedukung wisata melalui pokdarwis dengan berbagai kegiatan mendukung pariwisata.

Masing-masing pihakyang terkait atau stakeholder sebenarnya sudah berjalan, hanya saja peran dari masyarakat yang sekarang sudah menurun karena sudah banyak non-aktifnya pokdarwis di masingmasing desa. Tetapi sebagai gantinya masyarakat sekitar juga ikut berperan dalam mengambil alih penyediaan fasilitas pendukung wisata seperti penyediaan alat permainan pantai, sehingga dapat mendorong keterlaksanaan dari prinsipprinsip dalam sustainable tourism di kawasan wisata Rupat Utara.

Berdasarkan wawancara juga dapat dilihat bahwa ada berbagai peranan yang juga diisi oleh masyarakat sekitar sebagai bentuk dari keikutsertaan masyarakat dalam pengembangan pariwisata secara berkelanjutan, seperti ikut dalam gotongroyong membersihkan kawasan wisata ketika sebelum dan sesudah acara yang dilakukan disekitar lokasi wisata, menyediakan pengamanan, serta ikut serta juga dalam pelatihan-pelatihan yang disediakan oleh pemerintah sebagai bentuk pendukung perekonomian masyarakat sekitar untuk menambah keahlian 
diberbagai bidang dan dapat menjadi penghasilan yang diperjualkan kepada pengunjung yang berwisata ke Rupat Utara, seperti menyediakan oleh-oleh dan cendaramata khas Rupat Utara yang dapat dibawa pulang oleh wisatawan yang telath berkunjung.

Berdasarkan analisis yang telah peneliti lakukan, maka dapat disimpulkan bahwa apek keikutsertaan para pelaku/Stakeholders dalam pengembangna pariwisata dalam perspektif Sustaunable Tourism di Rupat Utara Kabupaten Bengkalis sudah terpenuhi. Dapat dilihat bahwa masing-masing stakeholders sudah ikut serta berdasarkan perannya massingmasing dalam pengembangan pariwisata. Pemerintah dalam hal ini yaitu Dinas Pariwisata berperan dalam menyediakan fasilitas pendukung pariwisata yang ada di Rupat Utara yaitu dengan menyediakan gazebo, pergola, pendopo, jogging track, mushola, toilet.

\section{Kepemilikan Lokal}

Kepemilikan lokal ialah segala bentuk fasilita pendukung wisata yang dikelola dan kepemilikannya oleh masyarakat disekitar wisata. Fasilitas yang ada di Kawasan wisata Rupat Utara seperti penginapan dan juga rumah makan merupakan kepemilikan dari warga lokal atau masyarakat tempatan yang berupa hotel/penginapan, dan juga ada rumah-rumah warga disekitaran kawasan wisata yang dijadikan sebagai homestay.

Kepemilikan dan juga pengelola dari fasilitas pendukung tersebut juga adalah masyarakat yang merupakan pemilik tempat tersebut. Fasilitas yang kepemilikannya oleh Pemerintah daerah saat ini seperti gazebo, pergola, jogging track, toilet, tempat ibadah, gapura, dan pendopo yang masih dalam proses pembangunan. Selain itu, pantai juga kebanyakan adalah milik swasta atau perorangan dan hanya 2 hektar saja milik pemerintah daerah.

Kepemilikan lokal yang dimiliki oleh swasta di Kawasan Pantai ini juga ada kontribusinya terhadap pengembangan pariwisata di Rupat Utara yaitu ikut serta dalam menyediakan fasilitas pendukung dan juga wisata-wisata pendukung baru disekitaran pantai yag berupa ayunan, gazebo ditepi pantai, tempat duduk, ayunan, dan spot-spot foto menarik yang khusus disediakan disekitaran penginapan dekat wisata Rupat Utara. Spot foto merupakan hal yang penting harus ada di suatu tempat wisata karena wisatawan ketika datang tentunya akan berfoto ditempat yang menurut mereka bagus. Tentu saja dengan adanya fasilitas pendukung yang disediakan oleh swasta ini akan lebih manarik minat pengunjung dan secara tidak langsung menjadi sarana promosi wisata juga. 
Berdasarkan analisis yang telah peneliti lakukan, maka dapat disimpulkan bahwa aspek kepemilikan local dalam pengembangan pariwisata dalam perspektif Sustaunable Tourism di Rupat Utara Kabupaten Bengkalis belum terpenuhi, hal ini dapat dilihat dari lahan sekitar pantai milik Pemerintah Daerah hanya seluas 2 hektar saja, sedangkan sellebihnya adalah milik perorangan yang mana kebanyakan adalah milik orang luar daerah yang membeli lahan dan bukan masyarakat lokal. Dengan sedikitnya lahan yang dimiliki pemerintah ini menyebabkan pengembangan tidak efektif karena susah untuk membangun fasilitas dan mengembangkan lahan sekitaran pantai karena milik pribadi. Hal ini pula menyebabkan pemandangan kurang indah dilihat disepanjang pantai yang terbengkalai dan tidak diurus oleh pemiliknya dan tidak dikelola dengan selayaknya.

\section{Pembangunan Sumber Daya Berkelanjutan}

Pengelolaan dan pengembangan pariwisata di Kawasan wisata Rupat Utara tentu saja dalam pembagunan fasilitas dan sarana memperhatikan kesediaan dalam mempertimbangkan dari segi lingkungannya. Selama ini penggunaan sumber daya alam disesuaikan dengan keterbutuhan dalam pembangunan dan tetap menjaga kelestarian alam yang sudah ada.
Pembangunan sumber daya berkelanjutan di kawasan wisata Rupat Utara dinilai belum baik karena masih banyak lahan sekitaran wisata belum dikelola dengan baik, terutama dalam pelestarian lingkungannya masih buruk yang dapat dilihat dari masih banyaknya sampah yang berserakan disekitaran pantai . Masih banyak juga lahan semak belukar padahal masih disepanjang pinggiran pantai. hal yang menghambat pembangunan sumber daya berkelanjutan disini yaitu disebabkan oleh lahan yang kebanyakan dimiliki oleh perorangan namun tidak dikelola dengan baik, namun pemerintah daerah juga memiliki keterbatasan tindakan dalam pengelolaan karena lahan tersebut bukan hak kelola pemda untuk menjaga kelestarian lingkungannya.

Berdasarkan analisis yang telah peneliti lakukan, maka dapat disimpulkan bahwa aspek pembangunan sumber daya berkelanjutan dalam pengembangna pariwisata dalam perspektif Sustaunable Tourism di Rupat Utara Kabupaten Bengkalis belum terpenuhi. Hal ini dapat dilihat dari lahan sekitar Kawasan wisata tertutama wisata pantai yang belum dikelola dengan baik. Hal ini dapat dilihat dari sampah yang masih berserakan dikawasan sekitar pantai dan juga penumpukan barang-baranng bekas bangunan ayng terbengkalai begitu saja. 
5. Mewadahi

Tujuan-Tujuan Masyarakat

Dalam hal mewadahi tujuan masyarakat, tentunya masyarakatitu sendiri diikut sertakan dalam proses perencanaan untuk pengembangan pariwisata di Kawasan wisata Rupat Utara. Masyarakat diikutsertakan dalam penyusunan rencana pembangunan daerah terutama pada sektor pariwisata yaitu pada saat musyawarah rencana pembangunan (musrenbang) yang diadakan satu tahun sekali. Sehingga masyarakat ikut serta dalam penyusunan rencana pembangunan daerah.

Pengembangan

pariwisata berkelanjutan ini tentunya ada banyak sekali hal yang harus diperhatikan oleh Pemerintah Daerah dan tetntunya masyarakat mengambil peran penting dalam hal ini karena daerah tempat mereka tinggal yang akan dibangun dan masyarakat bisa memberikan masukan untuk membantu pemerintah melengkapi apa saja yang diperlukan dalam usaha mengembanggkan pariwisata di Rupat Utara ini. oleh karena itu dapat kita lihat dari wawancara diatas bahwa pemerintah memnahas aspirasi dari masyarakat ini didalam musrenbang. Dalam hal pemenuhan tjuan masyarakat ini, biasanya lebih spesifik masyarakat meminta untuk pembangunan infrastruktur yaitu jalan. Kondisi infrastruktur jalan sangat penting karena kondisi jalan juga dapat mempengaruhi perekambangan pariwisata, dengan kondisi jalan yang baik maka wisatawan akan lebih tertarik untuk mengunjungi kawasan wisata tersebut. Tapi sayangnya, kondisi jalanan menuju kaasan wisata Rupat Utara ini sulit dibangun karena masalah dana yang dibutuhkan cukup tinggi dibandingkan membangun di daratan. Kondisi pulau Rupat yang merupakan pulau yang letaknya jauh dari kota dan juga harga bahan untuk pembangunan infrastruktur lebih mahal menjadi salah satu kendala terhambatnya pengembangan pariwisata di Rupat Utara.

Berdasarkan analisis yang telah peneliti lakukan, maka dapat disimpulkan bahwa aspek mewadahi tujuan-tujuan masyarakat dalam pengembangan pariwisata dalam perspektif Sustaunable Tourism di Rupat Utara Kabupaten Bengkalis belum terpenuhi. Sebenarnya masyarakat sudah diikutsertakan dalam berbagai kegiatan yang dilakukan pemerintah dalam mengembangkan Kawasan wisata Rupat Utara ini, namun tujuan masyarakat yang sangat sering diminta namun tidak kunjung terwujud yaitu dalam perbaikan infratruktuur jalan. Padahal, jalan merupakan hal yang sangat peenting untuk menunjang daya Tarik wisatawan berkunjung serta memudahkan 
mobilitas masyarakat dalam kegiatan sehari-hari seperti menjual dagangan keluar daerah dan lainnya. Tetapi permintaan untuk penyediaan jalan ini dari tahun ketahun tak kunjung direalisasikan oleh pemerintah daerah.

\section{Daya Dukung}

Rupat Utara sudah memiliki alam yang sangat luarbiasa indahnya. Salah satunya adalah pasir putih yang membentang luas dan airnya jernih berwarna hiijau,serta kondisi lautnya yang tenang sehingga menyebabkan wisatawan yang terus berdatangan untuk menikmati keindahan alam terutama pantai yang ada di Rupat Utara. Selain memiliki alam yang indah, penyediaan fasilitas untuk memenuhi kebutuhan wisatawan terus ditingkatkan untuk memberikan rasa nyaman kepada wisatawan ketika berwisata di Kawasan wisata Rupat Utara dan dapat meningkatkan jumlah wisatawan yang datang berlibur untuk menenangkan diri dari hiruk-pikuk kota dengan menikmati keindahan alamnya yang masih asri. Ada beberapa daya dukung wpariwisata yang ada di Rupat Utara mulai dari wisata alam, wisata budaya, dan wisata buatan.

Keterbatasan keadaan membuat segala kegiatan festival tahunan yang semstinya dibuka untuk umum dan menjadi moment yang ditunggu-tunggu tiap tahunnya oleh masyakat sekitaran kawasan wisata Rupat Utara maupun para wisatawan yang ingin berkunjung menjadi terhambat dan dilakukan terbatas serta tidak bisa dinikmati oleh wisatawan karena tidak bisa berkunjung, padahal acara tersebut merupakan daya dukung paling berpengaruh yang mendatangkan wisatawan paling banyak dari pada hari biasanya. Namun dimasa pandemi ini, pihak Kecamatan Rupat Utara mencari daya alternatif daya dukung lain seperti menggunakan teknologi saat ini melalui promosi wisata di sosial media. Jika keadaan sudah membaik, maka kawasan wisata Rupat utara dapat menjadi salah satu list dari tujuan wisata para wisatawan.

Berdasarkan analisis yang telah peneliti lakukan, maka dapat disimpulkan bahwa aspek daya dukung dalam pengembangan pariwisata dalam perspektif Sustaunable Tourism di Rupat Utara Kabupaten Bengkalis sudah terpenuhi. Hal ini dapat dilihat dari Ketersediaan dari fasilitas yang mendukung kegiatan wisatawan seperti homestay dan penginapan milik swasta atau masyarakat setempat, segala fasilitas umum milik pemda yang ada di sekitaran kawasan wisata dan beberapa bangunan fisik yang sedang dibangun seperti pendopo merupakan daya dukung untuk menunjang pengembangan pariwisata yang ada di 
kawasan wisata Rupat Utara. Adanya festival yang dilakukukan setiap tahun dikawasan wisata Rupat Utara sebagai promosi wisata juga merupakan daya dukung wisata. Pemerintah Daerah juga telah merencanakan pembuatan aplikasi khusus untuk mempermudah wisatawan yang ingin berkunjung untuk memesan hotel dan segala kemudahan yang akan dinikmati nantinya ketika berkunjung.

\section{Monitoring dan Evaluasi}

Monitoring merupakan aktifitas yang ditujukan untuk memberikan informasi tentang sebab dan akibat dari suatu kebijakan yang sedang dilaksanakan, kemudian evaluasi adalah kegiatan untuk menilai tingkat kinerja suatu kebijakan. Untuk monitoring dan evaluasi dalam pengembangan pariwisata di Kawasan wisata Rupat Utara monitoring dan evaluasi yang dilakukan oleh pemerintah daerah berupa musyawarah rencana pembangunan (musrenbang) yang itu dilaksanakan satu tahun sekali. Saat musrenbang tersebut pemerintah daerah melakukan monitoring dan evaluasi terhadap keberjalanannya kebijakan dalam pengembangan pariwisata di Kecamatan Rupat Utara pada saat sebelumnya.

Dalam pelaksanaan monitoring dan evaluasi terhadap pengembangan pariwisata di Kawasan wisata Rupat Utara dilakukan pada saat musrenbang. Monitoring dan evaluasi yang telah dilakukan dirasa kurang maksimal oleh masyarakat dan swasta. Hal tersebut dikarenakan pelaksanaan musrenbang yang hanya dilakukan satu tahun sekali yang berarti untuk monitoring dan evalusi dengan frekuensi yang lama. Meskipun pemerintah ada juga melakukan kunjungan langsung dan evaluasi kegiatan kepada pihak terkait dilapangan, belum diketahui oleh beberapa pihak. Selain dari itu, pada saat musrenbang pembahasan terlebih pada infrastrukturdesa diluar dari pengembangan pariwisata di Kawasan wisata Rupat Utara, sehingga belum adanya monitoring dan evaluasi terhadap pengembangan pariwisatadi kawasan wisata Rupat Utara.

Berdasarkan analisis yang telah peneliti lakukan, maka dapat disimpulkan bahwa aspek monitoring dan evaluasi dalam pengembangna pariwisata dalam perspektif Sustaunable Tourism di Rupat Utara Kabupaten Bengkalis sudah terpenuhi. Hal ini dapat dilihat dari adanya kegiatan musrenbang yang dilakukan setiap satu tahun sekali. Meskipun hanya setahun sekali, hal ini diilai wajar karena memang biasanya agak sulit dan butuh waktu yang lama 
dalam Menyusun suatu program dan targetnya akan dilihat pekembangan dalam kurun waktu satu tahun dan sekalian mengevaluasi program serta dana yang dibutuhkan dalam pembangunan pariwisata di Kawasan wisata Rupat Utara ini.

\section{Akuntabilitas}

Dalam melihat akuntabilitas dari pengembangan pariwisata di kawasan Rupat Utara ini masih terdapat oknum swasta yang kurang bertanggung jawab yang mana mereka yang melanggar melakukan eksploitasi alam secara berlebihan dengan menggunduli lahan secara membakar dan menebang pohon dan mengambil pasir secara berlebihan sehingga menyebabkan kerusakan. Oleh karena itu, perlu adanya pengawasan atau regulasi terkait pemanfaatan dan pengelolaan lingkungan. Selain itu tetap melakukan pemeliharaan terhadap lingkungan. Penyediaan lapangan pekerjaan pun ikut menjadi pertimbangan untuk meningkatkan prekonomian masyarakat lokal.

Berdasarkan analisis yang telah peneliti lakukan, maka dapat disimpulkan bahwa aspek monitoring dan evaluasi dalam pengembangna pariwisata dalam perspektif Sustaunable Tourism di Rupat Utara Kabupaten Bengkalis belum terpenuhi. Hal ini dapat dilihat dari
Kurangnya pengetahuan masyarakat dan minat untuk mengelola lahan serta fasilitas yang ada baik dari pemerintah maupun swasta, menyebabkan kurangnya ketertarikan dan minat kunjung wisatawan. Selain itu , terdapat oknum yang melakukan pembangunan tanpa memperhatikan keadaan lingkungan yang ada, sehingga mengeksploitasi alam secara berlebihan, dan pembakaran lahan juga masih banyak terjadi dikarenakan kurangnya pengawasan dan regulasi terkait pemanfaatan dan pengelolaan lingkungan.

\section{Pelatihan}

Pelatihan yang sudah dilakukan oleh pemerintah sebenarnya sudah ada dan cukup baik karena adanya kepedulian pemerintah daerah dalam mengikutsertakan masyarakat dalam pengembangan pariwisata yang ada di Rupat Utara. Menurut informan pelatihan dalam pengelolaan homestay atau penginapan bagi wisatawan ini diberikan kepada masyarakat dan juga sekaligus pihak swasta yang ingin membuka usaha dibidang penyediaan fasilitas pendukung seperti penginapan/homestay yang tentu saja merupakan kebutuhan utama bagi wisatawan unyttuk bermalam serta menikmati keindahan alam lebih lama lagi.

Pengetahuan Sosial di sekolah dapat membangkitkan kesadaran siswa dalam hidup bermasyarakat, sehingga tumbuh 
adanya kesadaran kebersamaan dalam kehidupan sosial (Prianti, 2020). Dari pelatihan yang diberikan, maka akan muncul rasa ingin tahu serta ide baru dari peserta pelatihan untuk mengembangkan usaha yang mereka miliki. Sama halnya dalam pelatihan bidang kuliner, biasanya kuliner ini merupakan masakan melayu yang merupakan ciri khas masyarakat Rupat Utara, dan mengelola berbagai sumber daya alam yang ada disekitar sehingga dapat menjadi suatu makanan yang nantinya akan dijual Ketika ada event dan dapat menambah penghasilan masyarakat tempatan.

Berdasarkan analisis yang telah peneliti lakukan, maka dapat disimpulkan bahwa aspek pelatihan dalam pengembangan pariwisata yang berbasis sustainable tourism sudah terpenuhi. Hal ini dapat dilihat dari adanya kegiatan pelatihan yang diberikan oleh Pemerintah Daerah kepada masyarakat yaitu dalam bentuk pelatihan pemandu wisata, pelatihan bidang kuliner, pengelolaan homestay, dan lainnya. Pelatihan dilakukan dalam usaha peningkatan kualitas, pelayanan, dan pengelolaan objek wisata untuk meningkatkan minat masyarakat mencari peluang usaha dari potensi wisata yang ada. Pelatihan ini juga dinilai sudah diterapkan yang mana dapat dilihat bahwa sudah banyak homestay milik masyarakat tersedia disekitar Kawasan wisata terutama Kawasan wisata pantai.

\section{Faktor Penghambat}

\section{Komitmen}

Masyarakat selalu saja mengeluhkan kondisi jalan. Menurut masyarakat, untuk memajukan pariwisata memerlukan adanya faktor pendukung yang memadai, infrastukrur jalan merupakan suatu pondasi suksesnya pengembangan pariwisata, karena yang paling utama wisatawan pertanyakan yaitu mengenai transportasi dan keadaan jalan menuju lokasi wisata. Tidak banyak orang yang ingin berkunjung ke suatu wisata jika sulit untuk ditempuh dan memakan waktu serta resiko yang buruk, dan hal ini juga dapat mengurangi minat pengunjung. Sebenarnya, bisa saja pemerintah untuk membangun jalan jika diimbangi dengan komitmen yang kuat untuk membangun dan mengembangkan pariwisata yang ada di Rupat Utara. Salah satu cara yang bbisa ditempuh yaitu dengan menghadatangkan bahan baku pembangunan dari lluar Pulau, yang tentu saja akan jauh lebih murah dan diangkut dengan kapal pengangkut barang ke Pulau Rupat. Pemerintah daerah juga lebih bisa menganggarkan dari pendapatan daerah sehingga tidak hanya mengandalkan pusat saja. Karena itu, komitmen untuk membangun dan mengembangkan pariwisata di Rupat Utara harus dipegang 
teguh oleh Pemerintah Daerah sehingga pariwisata dapat lebih berkembang dan meningkatkan pendapatan daerah dibidang pariwisata.

\section{Keterbatasan Lahan}

Lahan sangatlah penting untuk membangun dan mengembangkan suatu kawasan wisata, sampai saat ini lahan yang bisa di pergunakan oleh dinas Pariwisata Kabupaten Bengkalis kurang lebih 2 Hektar, Sedangkan kementerian Pariwisata mengatakan bahwa untuk mengembangkan kawasan wisata diperlukan lahan sebesar 300 Hektar. Pada saat observasi kelapangan peneliti memang benar menemukan bahwa masih minimnya lahan yang dimiliki oleh pemerintah daerah khususnya Dinas pariwisata Kebudayaan Kepemudaan dan Olaharaga. Dengan terbatasnya lahan yang dimiliki menjadi Faktor Penghambat Pemerintah Kabupaten Bengkalis khusunya Dinas Pariwisata untuk membangun dan mengembangkan kawasan wisata di sekitar Kawasan Rupat Utara.

\section{Anggaran}

Faktor anggaran untuk pengembangan dan pembangunan kawasan wisata Rupat Utara yang berasal dari Anggaran Pendapatan Belanja Daerah (APBD) Kabupaten Bengkalis saja, sehingga dana tersebut masih kurang optimal. Padahal di kawasan Kecamatan Rupat Uutara Kabupaten Bengkalis memiliki banyak kawasan objek wisata, sehingga membutuhkan dana yang tidak sedikit.

Oleh sebab itu Dinas Pariwisata Kebudayaan Pemuda dan Olahraga Kabupaten Bengkalis harus pandai-pandai mempromosikan objek wisata yang ada dikawasan wisata Rupat Utara dan menarik investor untuk menanamkan modalnya pada sektor pariwisata, supaya pembangunan dapat terealisasikan dengan baik dan dapat meningkatkan pendapatan asli daerah. Diharapkan pemerintah daerah Kabupaten Bengkalis lebih memperhatikan pengembangan kawasan wisata ini agar dapat penunjang pariwisata Rupat Utara sehingga dapat berkembang dengan baik dan dapat dinikmati wisatawan dengan nyaman.

\section{KESIMPULAN}

Berdasarkan hasil penelitian yang dilakukan peneliti dilapangan, maka kesimpulan akhir dari peneliti mengenai Pengembangan Pariwisata dalam Perspektif Sustainable Tourism di Rupat Utara Kabupaten Bengkalis dapat disimpulkan sebagai Pengembangan pariwisata dalam perspektif Sustainable Tourismdi Rupat Utara Kabupaten Bengkalis melalui penerapan kesembilan prinsip sustainable tourism dikawasan wisata Rupat Utara belum berjalan secara keseluruhan. Faktor 
penghambat dalam pengembangan pariwisata dalam perspektif Sustainable Tourism di Rupat Utara Kabupaten Bengkalis terdiri atas tiga permasalahan yaitu, faktor komitmen, keterbatasan lahan, dan juga anggaran. Hal yang paling penting diperhatikan yaitu masalah koomitmen dari pemerintah untuk mengembangkan pariwisata yang ada sehingga dapat mengatasi masalah keterbatasan anggaran.

\section{DAFTAR PUSTAKA}

Creswell, J.W. 2013. Research Design Pendekatan Kualitatif, Kuantitatif, dan Mixed, edisi Ketiga. Yogyakarta: Pustaka Pelajar

Creswell, Jhon W. 2016. Research Design Pendekatan Kualitatif, Kuantitatif, dan Mixed. Yogyakarta: Pustaka Pelajar

Damatik, Janianton dan Helmut F. Weber. 2006. Perencanaan Ejowisata Dari Teori ke Aplikasi. Yogyakarta: Andi Offset

Herdiansyah, haris. 2010. Metodologi Penelitian Kuantitatif. Jakarta: Selemba Humanika.

Muljadi A.J dan Marwan Adri. 2014. Kepariwisataan dan Perjalanan. PT Raja Grafindo Persada. Jakarta

Prianti, E. N. (2020). Pengaruh Motivasi Belajar Terhadap Prestasi Belajar Ilmu Pengetahuan Sosial Siswa Sma Negeri Wilayah Kabupaten Pandeglang-Banten. Pro Patria: Jurnal Pendidikan, Kewarganegaraan, Hukum, Sosial, Dan Politik, 3(2), 115-128.
Sugiyono. 2016. Metode Penelitian Kualitatif. Bandung. Alfabeta

Yoeti, Oka A. 2016. Perencanaan Dan Pembangunan Pariwisata. PT. Balai Pustaka Persero: Jakarta

Utama, I Gusti B.R. 2016. Pengantar Industri Pariwisata. Yogyakarta: CV. Budi Utama

\section{Dokumen :}

Undang -Undang Nomor 2009 Tentang Kepariwisataan

Peraturan pemerintah Nomor 50 Tahun 2011 Tentang Rencana Induk Pengembangan Kepariwisataan Nasional (RIPPARNAS) Tahun 2010-2025.

Peraturan Daerah Kabupaten Bengkalis Nomor 11 Tahun 2016 Tentang Pembangunan Jangka Menegah (RPJM) Tahun 2016-2021

Rencana Induk dan Rencana Detail Kawasan Stategis Pariwisata Nasional (KSPN) Pengembangan Pulau Rupat Tahun 2016 